\title{
Why did a German newspaper insist the Oxford AstraZeneca vaccine was inefficacious for older people-without evidence?
}

\author{
Reporting information from single anonymous sources that turns out to be false could erode public \\ confidence in the vaccines that are crucial to controlling the covid-19 pandemic. Hristio Boytchev \\ reports
}

\section{Hristio Boytchev journalist}

"AstraZeneca vaccine apparently hardly effective in seniors," reported the German economic newspaper Handelsblatt on Monday 25 January. "Setback for vaccine" ran as its top story in print the next day, ${ }^{1}$ subtitled, "The AstraZeneca vaccine apparently has an effectiveness of only $8 \%$ in the elderly. The government's vaccination strategy is shaky."

Handelsblatt attributed news of $8 \%$ effectiveness among over $65 \mathrm{~s}$ to an anonymous government source. The story does not explain the calculation for this figure. There was no comment from AstraZeneca, and the German health ministry declined to answer questions about effectiveness.

With huge global public health implications, Handelsblatt's story rapidly became international news-and was rapidly rebuffed. Calls for the underlying data filled social media. An AstraZeneca spokesperson described the reported figure as "completely incorrect."

The controversy came at a moment of intense finger pointing between the European Commission and AstraZeneca over unfulfilled vaccine shipments, and in the week that the European Medicines Agency (EMA) was expected to decide whether to recommend authorisation.

By Friday 29 January the EMA had given the vaccine conditional authorisation for use in all ages and on 10 February the World Health Organization recommended the vaccine for all adults. Although the EMA warned that data for over 55 s was limited, ${ }^{3}$ it was now clear that the single digit effectiveness from Handelsblatt's story was baseless.

Many EU countries including Germany have restricted the vaccine's use for older people. 4 "It is not about critique of the vaccine, but of the lack of data," Thomas Mertens, head of the German Standing Committee on Vaccination (STIKO), told The BMJ. "When there is more and better data, STIKO will change its recommendation."

\section{Confusion compounded}

Earlier in the week, a column in US magazine Politico ${ }^{5}$ had compounded the confusion, quoting an anonymous British government source: " $8 \%$ is the percentage of people over 65 in the study, but not the efficacy. Not sure if the reporter got mixed up.”
The German health ministry repeated this speculation in an email to journalists: "At first sight, it seems that two things have been confused. About $8 \%$ of the subjects in the AstraZeneca efficacy trial were between 56 and 69 years of age" ( 974 out of 11636 ). ${ }^{6-8}$

But in a follow-up story Handelsblatt ${ }^{9}$ stood by the figure of $8 \%$, quoting an anonymous health ministry bureaucrat: "Confusion is out of the question. According to the data available to us so far, effectiveness in people over 60 is less than $10 \%$."

Two days later, however, the ministry's press office released draft recommendations to journalists from STIKO, marked confidential. "According to this, it is not possible to make a statement about the effectiveness of the AstraZeneca vaccine in people over 65 years," the email said.

The draft also recommended not using the vaccine in this age group. This news was covered widely without mentioning the recommendations' draft status. ${ }^{10}{ }^{11}$ Mertens said he was "annoyed" that the draft had been given to the press, ${ }^{12}$ adding that the data were clearly confidential.

The draft included a calculation that might have led to Handelsblatt's false claim. It states the AstraZeneca vaccine to be $6 \%$ effective in patients over 65 -but with a confidence interval of $-1405 \%$ to $94 \%$ this is meaningless. ${ }^{13}$ The final recommendations report "insufficient data for a robust statistical statement on effectiveness" for this age group.

\section{He says, she says}

Handelsblatt "turned the matter into a 'he says, she says' story to absolve itself of responsibility for spreading stupid stuff,” Markus Lehmkuhl, professor for science communication at the Karlsruhe Institute of Technology, told The BMJ. Avoiding "admission of its own error further unsettles the public and undermines confidence in the vaccine."

Lehmkuhl sees a fundamental problem: the desire to report precise numbers that suggest certainty. Handelsblatt's reporting was a "beginner's mistake," he said. "Precise scientific information" was attributed to a single "unsuitable source, who, to make matters worse, did not want to be quoted by name," Lehmkuhl said. "The journalists should have realised that such low effectiveness is implausible" given the efficacy reported in other age groups. 
Soon after the original story broke, journalists asked why a political story should be free from basic fact and plausibility checking. Gregor Waschinski, Handelsblatt's political correspondent, tweeted, "I understand that some would like to see the story substantiated with actual data. However, this is not an academic preprint but a sourced piece of political reporting." 14

Four days after publication, Handelsblatt changed the story online ${ }^{15}$ "to include current developments," changing the title to "Discussion about efficacy of AstraZeneca vaccine in seniors.”

Handelsblatt declined The BMJ's invitation to comment on why it had not made a correction. Despite inquiries from The BMJ, the ministry did not comment on its allegation about Handelsblatt's mistake or why it had released confidential draft recommendations to journalists.

Provenance and peer review: Commissioned; not externally peer reviewed.

Competing interests: I have read and understood BMJ policy on declaration of interests and have no relevant interests to declare.

1 Rückschlag bei Impfstoff. [German] Handelsblatt. 26 January 2021. https://epaper.handelsblatt.com/?ticket=ST-666147-AvOVZUrSb52HnzhIEDXp-ap1\#read/11/Handelsblatt/2021-01-26/1.

2 Expert reaction to reports from Germany that the Oxford-AstraZeneca covid-19 vaccines has $8 \%$ efficacy in over 65s. Science Media Centre. 25 January 2021. www.sciencemediacentre.org/expert-reaction-to-reports-from-germany-that-the-oxford-astrazeneca-covid-19-vaccine-has-8-efficacy-in-over-65s.

3 European Medicines Agency. EMA recommends covid-19 vaccine AstraZeneca for authorisation in the EU. 29 January 2021. www.ema.europa.eu/en/news/ema-recommends-covid-19-vaccineastrazeneca-authorisation-eu

4 Reality Check Team. Covid-19: Fact checking Macron's over-65s claim about the Oxford-AstraZeneca vaccine. BBC News. February 2021. www.bbc.co.uk/news/55919245.

5 Wickham A. Politico London Playbook: AZ vs EU-what's 8 percent in German-Jabba the cut. 26 January 2021. www.politico.eu/newsletter/london-playbook/politico-london-playbook-az-vseu-whats-8-percent-in-german-jabba-the-cut.

6 Voysey M, Clemens SAC, Madhi SA, et alOxford COVID Vaccine Trial Group. Safety and efficacy of the ChAdOx1 nCoV-19 vaccine (AZD1222) against SARS-CoV-2: an interim analysis of four randomised controlled trials in Brazil, South Africa, and the UK. Lancet 2021;397:99-111. doi: 10.1016/S0140-6736(20)32661-1 pmid: 33306989

7 Angeblich niedrige Wirksamkeit von AstraZeneca-Impfstoff-Ministerium vermutet Verwechslung [German]. Spiegel. 26 January 2021. www.spiegel.de/wissenschaft/medizin/corona-gesundheitsministerium-widerspricht-niedriger-wirksamkeit-von-astrazeneca-impfstoff-a-fOdf2116-f74a4385-ac47-56469f500293.

$8 \quad$ Wirkt Astrazeneca-Impfstoff Nicht bei Älteren? [German] Brisant. 26 January 2021. www.mdr.de/brisant/corona-impfstoff-astrazeneca-100.html.

9 Hofmann S, Siebenhaar HP, Waschinski G. Kontroverse um Impfstoff von Astra-Zeneca. [German] Handelsblatt 26 January 2021. www.handelsblatt.com/politik/deutschland/pandemiebekaempfungkontroverse-um-impfstoff-von-astra-zeneca/26854288.html.

10 Astra-Zeneca-Impfstoff nur für unter 65-Jährige. [German] Frankfurter Allgemeine Zeitung. 28 January 2021. www.faz.net/aktuell/politik/inland/stiko-empfiehlt-astrazeneca-impfstoff-nur-fuerunter-65-jaehrige-17169561.html.

11 AstraZeneca-Impfstoff nur für unter 65-Jährige. [German] Tagesschau. 28 January 2021. www.tagesschau.de/inland/stiko-astrazeneca-101.html.

12 Transcript: Zulassungsempfehlung der EMA und STIKO-Empfehlung ZU AstraZeneca-Impfstoff AZD1222. [German] Science Media Centre. 29 January 2021. www.sciencemediacenter.de/fileadmin/user_upload/Press_Briefing_Zubehoer/Transkript_Impfungen-EMA-STIKOEmpfehlung_AstraZeneca_SMC-Press-Briefing_2021_01_29.pdf.

13 Beschluss der STIKO zur 2 Aktualisierung der covid-19-Impfempfehlung und die dazugehörige wissenschaftliche Begründung. [German] Epidemiologisches Bulletin. Robert Koch Institute. 4 February 2021. www.rki.de/DE/Content/Infekt/EpidBull/Archiv/2021/Ausgaben/05_21.pdf?_blob=publicationFile.

14 Waschinski G. @washingtonski. 25 January 2021. https://twitter.com/washingtonski/status/1353841867029438465.

15 Waschinski G, Brors P, Hofmann S, Siebenhaar HP. Corona-Impfstoff: Diskussion um Wirksamkeit von Astra-Zeneca-Vakzin bei Senioren. [German] Handelsblatt. 29 January 2021. www. handelsblatt.com/politik/deutschland/pandemie-bekaempfung-corona-impfstoff-diskussion-um-wirksamkeit-von-astra-zeneca-vakzin-bei-senioren/26849788.html. 